\title{
O MOMENTO E O MODO DA CONSAGRAÇÃO EUCARÍSTICA UMA CONTRIBUIÇÃO DA TEOLOGIA ORTODOXA DE PAUL EVDOKIMOV
}

Nedio Pertile OFMCap

RESUMO: Favorecido desde o período conciliar, o diálogo ecumênico ajudou a superar, na Igreja Católica Romana, o clima de controvérsia em torno da epiclese eucarística e das questões relativas, graças ao retorno às fontes da teologia. $\mathrm{O}$ artigo procura mostrar a contribuição ecumênica do teólogo ortodoxo Paul Evdokimov sobre a epiclese eucarística, o momento e o modo da consagração eucarística, à luz da pneumatologia oriental e da atitude apofática.

PALAVRAS-CHAVE: Paul Evdokimov, pneumatologia, epiclese eucarística, apofatismo, diálogo ecumênico.

ABSTRACT: Favored since the conciliar period, the ecumenical dialog within the Roman Catholic Church helped to overcome the controversial climate on the Eucharistic epiclesis and concerning issues, thanks to the return to the theological sources. This paper aims to show the ecumenical contribution of the orthodox Theologian Paul Evdokimov on the Eucharistic epiclesis, the Eucharistic moment and consecrating way according to the Eastern Pneumatology and the apophatic attitude.

KEY-WORDS: Paul Evdokimov, Pneumatology, Eucharistic epiclesis, apophatism, ecumenical dialog. 
apofatismo (não definição) constitui o "fundamento e regra da gnosiologia na teologia ortodoxa"1. Fundado na experiência da transcendência radical e infinita de Deus, o apofatismo não significa agnosticismo nem rejeição em conhecer a verdade, mas catarse, elevação libertadora da influência mundana do pensamento, substituição do desejo incontido da investigação puramente racional pela comunhão deificadora donde brota o conhecimento experiencial da verdade. A lembrança da dimensão apofática da verdade tem a função de sentinela para alertar contra o perigo da razão incontida e da presunção de querer explicar tudo, além disso é de grande auxílio na sincronização dos passos dos cristãos orientais e ocidentais na busca da verdade.

Para evidenciar a importância do apofatismo em teologia, sobretudo em questões relativas à teologia eucarística, faz-se necessário voltarmos nossa atenção ao "pulmão oriental" do cristianismo. Contudo, em força da brevidade desse artigo, limitar-nos-emos a um autor ortodoxo: Paul Evdokimov (1901-1970). Esse teólogo leigo, russo de nascimento e francês de adoção, é pouco conhecido no Brasil, mas atual e instigante. Seus escritos têm contribuído muito ao diálogo ecumênico.

Evdokimov trata do momento e do modo de consagração eucarística no quadro da teologia eucarística à luz da pneumatologia oriental. A epiclese é uma das chaves de leitura para compreender a sua obra teológica ${ }^{2}$.

O interesse desse artigo não é reavivar as polêmicas do passado em torno do momento e do modo da consagração eucarística, e sim mostrar como o procedimento teológico-apofático de Evdokimov vem ao encontro da teologia católica pós-conciliar. Por isso, apresentaremos inicialmente o procedimento reflexivo desse autor em torno dessas questões; em seguida, recorremos aos diálogos ecumênicos oficiais entre a Igreja Católica Romana e a Igreja Ortodoxa para perceber como os caminhos de um lado e de outro, aparentemente em vias opostas, no final se cruzam, senão em consenso total, pelo menos em um consenso inicial.

${ }^{1}$ P. EVDOKIMOV, L'Orthodoxie, Paris: Desclée de Brouwer, 1979, p. 15 (= Ort).

${ }^{2} \mathrm{O}$ presente artigo é uma síntese de parte do primeiro capítulo e de parte da conclusão de nossa tese doutoral, apresentada no Instituto Santo Inácio - Centro de Estudos Superiores da Companhia de Jesus, Belo Horizonte, em 04 de abril de 2005, intitulada "Manifestado pelo Espírito Santo: Paulo Evdokimov: 'teologia sob o signo da epiclese". 


\section{A consagração eucarística segundo Paul Evdokimov}

\subsection{A consagração eucarística através da epiclese}

Familiarizado com os textos da Divina Liturgia ${ }^{3}$, Evdokimov desenvolve a teologia eucarística a partir da unidade entre a lex orandi e lex credendi, através da qual coloca em relevo a pneumatologia oriental. Graças à intervenção do Espírito, a liturgia manifesta a presença do Cristo vivo. É a ação do Espírito no tempo da Igreja, denominado "tempo do Espírito". A presença e a ação conjunta de Cristo e do Espírito estão no princípio da comunhão eclesial e trinitária. Da ação conjunta dos dois Consoladores, evidencia-se a importância da súplica incessante da Igreja pela vinda do Espírito para manifestar a presença de Cristo em todos os elementos constitutivos da liturgia eucarística.

A súplica dirigida ao Pai para que, por intermédio do Filho, envie novamente o Espírito, não se reduz à grande epiclese da consagração das oferendas. Com efeito, a Divina Liturgia contém várias epicleses ou súplicas pela sua vinda sobre a assembléia e as oferendas. É neste contexto litúrgico epiclético-pentecostal que se situam as palavras da instituição. Evdokimov constata, inicialmente, uma diferença entre a tradição oriental e a ocidental. Enquanto o Ocidente atribui valor consecratório às palavras da instituição eucarística, ditas por Jesus na última ceia e repetidas pelo sacerdote, o Oriente o atribui à epiclese. Enquanto no Ocidente, as palavras institucionais são pronunciadas pelo sacerdote in persona Christi, o que lhe confere valor consecratório imediato, no Oriente esse modo de entender a função do sacerdote é "absolutamente desconhecida, até mesmo impensável" ${ }^{\prime 4}$. Não é pela simples repetição de palavras, mesmo bíblicas, que o sacramento se realiza. A epiclese é necessária para que as palavras da instituição eucarística obtenham valor consecratório; ademais, essas também são colocadas sob o arco epiclético da liturgia eucarística. Assim,

para que a palavra de Cristo, memorializada [mémorisée] pelo sacerdote, se cumpra e adquira eficácia divina, o sacerdote invoca o Espírito Santo na epiclese. Das palavras da anamnese pronunciadas pelo sacerdote: "tendo tomado o pão ... entregou-o aos seus discípulos dizendo ... isto é meu corpo", o Espírito faz anamnese epifânica, manifesta a intervenção do Cris-

\footnotetext{
${ }^{3}$ Expressão que designa, no rito bizantino, a celebração da eucaristia, ou simplesmente a eucaristia. Sintetizando e contendo toda a economia da salvação, a Divina Liturgia reproduz iconograficamente a liturgia celeste do Cordeiro (cf. Ap 5-7), por isso, centro da vida espiritual e sacramental da Igreja.

${ }^{4}$ Ort 250.
} 
to identificando as palavras pronunciadas com suas próprias palavras: é o milagre da metabolé [conversão das oferendas] ${ }^{5}$.

A transformação das oferendas em corpo e sangue de Cristo através da epiclese é uma tradição considerada segura e unânime entre os Padres do Oriente, tradição mantida inclusive entre os nestorianos e monofisistas. "A transformação do pão em corpo do Senhor efetua-se unicamente pela potência do Espírito Santo", escreve João Damasceno, sintetizando a tradição oriental $^{6}$. A súplica sacerdotal dirigida ao Pai pelo novo envio do Espírito sobre as oferendas confessa a fé especificamente cristã da ação operativa e pessoal da terceira Pessoa divina:

\begin{abstract}
A tradição patrística do Oriente é unânime em atribuir a potência operativa em todos os 'ritos sagrados' à intervenção hipostática da terceira Pessoa divina: ao Espírito Santo procedente do Pai e enviado pelo Filho para levar universalmente a termo a economia salvífica. Criador de vida, o Espírito é o órgão direto da vida espiritual, o agente supremo de todas as encarnações do celeste, fonte da graça e das energias divinas no seio da Igreja. Ele, Paráclito e fogo celeste, desce sobre toda carne, santificando-a e [con]sagrando-a ${ }^{7}$.
\end{abstract}

A unanimidade da tradição do Oriente em atribuir a consagração das oferendas à epiclese deve-se à própria pneumatologia dos Padres, que vêem no Espírito o princípio de toda manifestação divina no mundo. O princípio da intervenção pessoal do Espírito é concebida de modo exemplar e excelente na transformação dos dons eucarísticos, mas estende-se a todos os sacramentos, cuja matéria o Espírito transforma em instrumento ou veículo de suas energias deificantes, santificantes. Isso supõe que todos os sacramentos tenham necessariamente sua própria epiclese:

A metamorfose realizada em cada sacramento exige a intervenção do Princípio santificador em pessoa, que faz da matéria dos sacramentos o veículo de suas energias. É por isso que todos os sacramentos têm a sua própria epiclese, e se realizam mediante a descida do Espírito Santo ${ }^{8}$.

Os Padres compreendem a intervenção hipostática do Espírito na economia sacramental da Igreja à luz da economia salvífica. Se a ordem da criação segue um movimento descendente - do Pai, através do Filho, no Espírito - , a ordem da salvação segue um movimento contrário: começa no Espírito, através do Filho e culmina no Pai. Assim, na economia salvífica, o acesso ao Pai por intermédio do Filho só é possível, desde o início, pela ação do Es-

${ }^{5}$ La Prière de l'Église d'Orient: la liturgie byzantine de saint Jean Chrysostome, Paris: Casterman; Mulhouse: Salvator, 1996, p. 81 [grifos do autor] (= PEO).

6 JOÃO DAMASCENO, De fide orthodoxa 4, 3: PG 94, 1146 (apud PEO 80).

${ }^{7}$ PEO 77.

8 "La coupe de vie et l'Esprit Saint", Parole \& Pain n 26 (1968) 161-171, aqui p. 165. 
pírito Santo. O Espírito Santo é princípio de toda santificação no mundo e princípio de comunhão das criaturas com Deus: "Basílio define claramente a sua função ministerial. 'A criatura não possui dom algum que não the venha do Espírito; ele é o santificador que nos reúne a Deus'"'9.

Depois da ascensão, é o Espírito quem precede Cristo em suas manifestações salvíficas. A partida de Cristo deste mundo inaugura uma nova forma de presença no mundo, de modo especial nos sacramentos, não mais de forma visível, mas invisivelmente por meio do Espírito e no Espírito. Assim, para que o pão e o vinho se mudem realmente no corpo e sangue de Cristo, e os comungantes sejam integrados na comunhão de seu corpo (Igreja), a epiclese do Espírito se faz necessária.

"Se, pois, depois da ascensão de Jesus, é somente no e pelo Espírito que o Cristo está presente, a manifestação da presença eucarística do Cristo não pode ser feita senão pela intervenção do Espírito Santo, o que sublinha toda a importância da epiclese" ${ }^{\prime 10}$. "A parusia do Cristo na eucaristia se faz na e pela parusia do Espírito Santo (Jo 14-17) que opera o metabolismo dos dons e do próprio comungante"11.

A transformação escatológica dos dons e da assembléia ocorre graças à intervenção do Espírito, pois é o Espírito quem realiza a incorporação dos dons e dos comungantes ao Cristo celeste, numa espécie de misteriosa transferência para uma realidade invisível. Mas isso não significa nenhum pneumatocentrismo no mistério da consagração eucarística. A epiclese eucarística especifica a relação de reciprocidade e de mútuo serviço entre o Espírito e Cristo na economia da salvação: Cristo, conforme sua promessa, envia o Espírito "de junto do Pai" (Jo 15,26), e o Espírito manifesta Cristo ao mundo, ambos convergindo na única revelação do Pai. Para os Padres orientais, existe uma relação dinâmica entre a humanidade de Cristo e o Espírito, o qual atua como "unção", testemunho e manifestação de sua humanidade. A humanidade do Cristo subsiste, mas pneumatizada. Esta ação dinâmica do Espírito no Filho continua naqueles que comungam as espécies eucaristizadas: à encarnação de Deus, responde a deificação do ser humano.

\subsection{A não definição do momento da consagração eucarística}

Evdokimov observa que a Ortodoxia não explica o modo nem define o momento em que ocorre a transformação dos elementos eucarísticos, limitando-se simplesmente a confessá-la através da epiclese, como escreve J. Breck: "A teologia eucarística ortodoxa recusa-se a especificar o modo ou

${ }^{9}$ BASÍLIO DE CESARÉIA, De Spiritu Sancto 16, 37: SC 17bis, 374 (apud PEO 78).

10 "Eucharistie, mystère de l'Église", La Pensée Orthodoxe no 13 (1968) 53-69, aqui p. 61.

${ }^{11}$ Ort 250. 
o momento dessa transformação sacramental. Ela reconhece, no entanto, na epiclese, o ápice da iniciativa divina e, por sua vez, humana"12.

Partindo do dado litúrgico que a celebração eucarística é atravessada por várias epicleses prévias sobre os dons e os fiéis, as quais se elevam como ondas cada vez mais altas até a grande epiclese da consagração, Evdokimov considera impossível isolar o momento preciso em que ocorre a consagração, haja vista que, para os orientais, a liturgia é uma ação única, um conjunto único de palavras e ritos que não se podem separar, como numa grande sinfonia.

Antes da epiclese propriamente dita: "Envia teu Espírito Santo sobre nós e sobre os dons aqui apresentados... transformando-os pelo teu Espírito Santo", a liturgia é atravessada desde o início por epicleses prévias, elevandose gradualmente até a palavra final. [...] Assim, é impossível isolar o instante preciso em que se opera a mudança [das oferendas], porque todo o cânon eucarístico e, pode-se mesmo dizer, toda a liturgia, a partir da proskomídia ${ }^{13}$, é um único Ato que se conclui na epiclese. Toda a liturgia, a partir de seu princípio, palpita neste ponto culminante e nesta invocação global e magnifíca que, em certo sentido, arranca [arrache] a resposta do Deus Filantropo. A epiclese é a última nota, o acorde final da inteira e única sinfonia. Assim, o ato é um todo orgânico decomposto, e não se pode fixar senão o momento após o qual o sacramento já é considerado realizado ${ }^{14}$.

A fixação de um momento preciso ou mesmo a atribuição de poderes mágicos a certas palavras proferidas durante a liturgia eucarística não condizem com a Ortodoxia. Não se pode cronometrar a misteriosa ação de Deus nas realidades do mundo. Não existe uma necessidade absoluta de que palavras ditas por Jesus e repetidas nos sacramentos, contenham a eficácia, pois o poder do sacramento eucarístico reside na Igreja, que invoca em cada ação sagrada um novo Pentecostes. O sentido das palavras litúrgicas deve ser compreendido a partir do que se celebra, de seu contexto eucológico, e não de alguma fórmula isolada.

É sem importância procurar, para cada sacramento, uma palavra explicitamente institucional do Senhor. Certamente, uma referência escriturística é sempre requerida, mas todo sacramento remonta à potência do Sacramento dos sacramentos que é a Igreja-eucaristia. O lado formal e jurídico não é operante nos sacramentos. Se, por razões válidas, na realização de um sacramento, as condições canônicas são deficientes, 'a graça supre a fraqueza humana', e a integração à eucaristia pode testemunhar a descida do Espírito Santo e o dom recebido. É por isso que, na prática antiga, todo sacra-

${ }^{12}$ J. BRECK, "Confession de foi et célébration liturgique", Unité Chrétienne $\mathrm{n}^{\circ} 69$ (1983) 61-81, aqui p. 75 .

${ }^{13}$ Proskomídia: rito de preparação das oferendas na liturgia bizantina. Também chamado prótese, esse rito antecede a Liturgia da Palavra.

${ }^{14}$ PEO 77-78. 
mento era uma parte orgânica da liturgia eucarística e recebia seu acabamento [se parachevait] na refeição do Senhor ${ }^{15}$.

A invocação que pede especificamente a transformação das oferendas e dos comungantes através da ação do Espírito Santo é, sem dúvida, um momento privilegiado da liturgia eucarística, mas não se pode isolá-la do conjunto da liturgia. Sem determinar o momento preciso em que se realiza a conversão das oferendas, cabe aos que dela tomam parte, uma atitude de veneração e reconhecimento por estarem diante de um mistério. E, no final da liturgia, depois de receberem a comunhão, os fiéis proclamam o mistério realizado:

Cristo, o mistério de tua economia terminou, enche nossos corações de alegria e regozijo. Todos proclamam o Mistério vivido realmente e é necessário dar todo valor à verdadeira e emocionante confissão do milagre: Nós vimos a verdadeira Luz, nós recebemos o Espírito celeste... Bendito seja o Nome do Senhor, agora e para sempre ${ }^{16}$.

Diante do mistério realizado pela resposta favorável de Deus à súplica da Igreja pela descida de seu Espírito, Evdokimov prefere manter uma atitude de reverência e de apofatismo (não definição), evitando assim a presunção de cronometrar a liberdade e os sopros transfiguradores do Espírito; manifesta, outrossim, fidelidade ao espírito da própria lex orandi que compreende a liturgia eucarística como um conjunto inseparável de palavras, gestos e ritos em que se elevam contínuas súplicas da assembléia a Deus e se louvam as suas incessantes descidas num "renovado Pentecostes".

\subsection{A não definição do modo da consagração eucarística}

Mantendo a mesma atitude apofática e de veneração em relação ao momento da consagração eucarística, Evdokimov recusa-se também a definir o modo pelo qual ocorre essa transformação. A inefabilidade e a insondabilidade dos mistérios divinos transcendem as categorias humanas de pensamento, por isso segue a "santa reserva" ortodoxa. Os autores ortodoxos, na via de João Damasceno, reiteram esse rechaço ${ }^{17}$, limitandose a confessar simplesmente a misteriosa realidade da transformação:

Através de seu sentido de veneração levado ao extremo, o Oriente jamais questionou o "quê" nem o "como" do mistério eucarístico. Uma vez o

${ }^{15}$ Ort 265.

${ }^{16}$ PEO 192-193, citando textos da Divina Liturgia [grifos do autor].

17 "Se tu perguntas como isto acontece, basta saber que sucede através do Espírito Santo, do mesmo modo como o Senhor formou uma carne para si e em si, da Santa Mãe de Deus. E não nos é dado saber mais, senão que a palavra de Deus é verdadeira, eficaz e onipotente, porém, o 'como' não é passível de investigação" (JOÃO DAMASCENO, De fide orthodoxa 4, 13: PG 94, 1145). 
milagre realizado, não há mais do que a carne e o sangue transfigurado da Vítima ressuscitada no cálice ${ }^{18}$.

A conversão dos dons é expressa pelo termo metabolé ( $\mu \varepsilon \tau \alpha \beta \circ \lambda \eta ́$ : mudança, conversão, transformação), utilizado com muita simplicidade pelos Padres e pelos textos das anáforas eucarísticas. A explicação de como ocorre a metabolé dos dons está totalmente ausente nos Padres. Na via da tradição patrística e da lex orandi, nas quais funda e alimenta seu pensamento teológico e sua espiritualidade eucarística, Evdokimov vale-se do mesmo termo para afirmar que tanto o modo da transformação das oferendas, quanto o que a epiclese realiza é simples e exclusivamente objeto de fé, por isso, realidade não suscetível de investigação do tipo filosófico fisicista.

Professando o ultra-realismo do ato de fé, Evdokimov evoca a equação atanasiana "pão igual corpo, vinho igual sangue", reconhecendo-a muito explícita nos Padres, sempre, porém, em referência a Cristo transfigurado e deificado pelas energias do Espírito Santo. Em linguagem simples e lapidar, própria de seu estilo, diz: “Do pão e do vinho, o Espírito faz a carne e o sangue do Cristo" ${ }^{\prime 19}$.

Como a Igreja ortodoxa não tem uma definição dogmática sobre a doutrina eucarística, os teólogos ortodoxos devem recorrer à tradição bíblica e patrística, evitando apoiar-se em enunciados filosóficos. Trata-se de corrigir o modo de considerar o mistério eucarístico, partindo do ponto de vista cristológico e não do ponto de vista material das espécies eucarísticas como fez a teologia latina do segundo milênio. A doutrina eucarística, na Ortodoxia, é sustentada pelo teandrismo do dogma calcedoniano: união entre o elemento divino (ação de graças, eucaristia, doxologia) e o elemento humano (súplica da Igreja e materialidade dos dons eucarísticos), porém "sem confusão, sem separação". O sinergismo teândrico (unidade, liberdade e harmonia entre a ação divina e a ação humana) ilumina o ponto de partida da inteligência teológica da consagração eucarística:

A glória dos concílios é de rejeitar o dualismo nestoriano (da separação entre o divino e humano) e o monofisismo (apenas o divino, dissolvendo o humano), e de estabelecer assim o teandrismo, fundamento inquebrantável do sinergismo do agir divino e do agir humano. $\mathrm{O}$ di-fisismo e o ditelismo (harmonia das duas natureza e das duas vontades em Cristo) forjam a chave de ouro para todo problema teológico ${ }^{20}$.

18 PEO 73 [grifos do autor].

19 "L’Esprit saint et la prière pour l'unité", Verbum Caro n ${ }^{\circ} 55$ (1960) 250-264, aqui p. 252.

${ }^{20}$ Ort 14 [grifos do autor]. J. Meyendorff escreve: "É sobre o pano de fundo da doutrina patrística grega da 'sinergia' que se pode compreender verdadeiramente o significado da insistência bizantina sobre a epiclese na liturgia eucarística, outro problema discutido nos séculos XIV e XV pelos teólogos gregos e latinos. O texto da 


\section{a) O milagre metafísico da metabolé eucarística}

A indefinível realidade da consagração eucarística é, segundo Evdokimov, "milagre" e "mistério". A mesma definição é aplicada a todos os sacramentos: "[...] os sacramentos da Igreja ocupam o lugar dos milagres do tempo da encarnação" 21 . A razão humana não tem condições de explicar nem de perceber o "milagre eucarístico", pois, sendo uma realidade cujo acesso é exclusivo da fé, apresenta a sua própria antinomia. Não se pode comparálo a uma mutação de ordem física:

O milagre eucarístico apresenta a mais radical antinomia que se possa con-

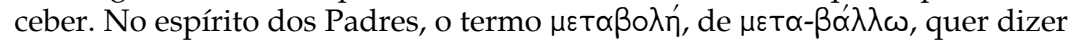
"lançado ou projetado além"; é evidente que não se pode explicar ou definir acerca de uma matéria cósmica projetada, elevada "além" dela mesma e assimilada pelo transcendente. A operação é meta-empírica, metalógica e antinômica porque ela exprime a identidade do diferente e a diferença do idêntico. Nesta identidade entre um significante material e um significado não-material, um não é absorvido nem destruído pelo outro; a sua identificação é dinâmica, in actu, ela deixa cada um em sua própria realidade, em seu próprio status quo. Aqui, a antinomia significa que uma realidade é o que não é, e não é o que é. O pão e o vinho são o corpo e o sangue, e o corpo e o sangue são o pão e o vinho. Não é uma transformação física onde o terminus a quo passa ao terminus ad quem, como a água passa totalmente a vinho nas Bodas de Caná22.

Nesse transcensus metafísico, por isso mais do que uma conversão física, trata-se de uma identificação de duas realidades ontologicamente distintas. Se o milagre eucarístico fosse de ordem física, ocorreria uma substituição dos elementos materiais, sempre permanecendo a materialidade cósmica, como é o caso da água transformada em vinho, em Caná da Galiléia (cf. Jo 2,1-11). Em se tratando de um milagre de ordem metafísica, a matéria cósmica transforma-se em uma realidade que não é deste mundo.

Se, nas bodas de Caná, a água se muda em vinho, é uma matéria deste mundo que deixa lugar à outra, porém sempre da natureza deste mundo: o milagre é físico. Na eucaristia, o pão e o vinho, matéria deste mundo,

epiclese, como aparece no cânon da liturgia eucarística de João Crisóstomo e em outras liturgias orientais, implica que o mistério se realiza mediante uma oração de toda a Igreja ('Nós te pedimos...'). [...] Como comunhão e 'sinergia' divino-humana, a eucaristia é a oração dirigida ao Pai 'em Cristo' e realizada através da descida do Espírito Santo. A epiclese é, portanto, o cumprimento da ação eucarística, justamente como o Pentecostes é o cumprimento da 'economia' divina da salvação: a salvação é sempre trinitária. A ação pneumatológica da eucaristia é pressuposta também na noção de 'sinergia'; é o Espírito Santo que torna o Cristo presente no tempo que intercorre entre as duas vindas, em cuja ação não se impõe à humanidade, mas se oferece para a livre aceitação da liberdade humana, e, entregando-se ao homem, torna-o autenticamente livre" (J. MEYENDORFF, La teologia byzantina: sviluppi storici e temi dottrinali, Casale Monferatto: Marietti, 1984, pp. 250-251).

${ }^{21}$ Ort 263.

${ }^{22}$ "Eucharistie, mystère de l'Église", art. cit., p. 58. 
metamorfoseiam-se em uma realidade que não é mais deste mundo: "o pão torna-se o Cordeiro celeste": o milagre é metafísico ${ }^{23}$.

A transformação do pão e do vinho, que acontece fora dos limites deste mundo, é o único caso de "identidade do diferente", pois ultrapassa a lei da identidade sem destruí-la. É por isso que o vinho da festa de Caná podia ser percebido pelos sentidos naturais, enquanto que o sangue eucarístico só pode ser percebido pela fée ${ }^{24}$.

Não é "um no outro", nem "um e outro" fisicamente, mas um é o outro metafisicamente, o que coloca a realidade miraculosa fora de toda a percepção sensível inerente às coisas deste mundo ${ }^{25}$.

Na tentativa de perscrutar o mistério da metabolé, porém sempre em atitude apofática, Evdokimov percebe uma semelhança entre a transformação eucarística e a transfiguração de Jesus sobre o monte Tabor: aí não é o Cristo que se transforma e sim "os olhos dos apóstolos que se abrem por um instante". Do mesmo modo, o mistério da metabolé eucarística também só é acessível na fé.

\title{
b) Metabolé eucarística e estado teândrico de Cristo
}

O caráter transcendente da metabolé eucarística, sustentado pela doutrina teândrica, permite perceber a união de duas realidades ontologicamente distintas, "sem confusão e sem separação". Só é possível compreender essa identificação partindo do estado glorioso (teândrico) de Cristo. Tal identificação não seria possível se partíssemos do estado quenótico do Jesus histórico:

\begin{abstract}
No momento da santa ceia, Cristo estava visivelmente presente sob forma terrestre, e também estava presente de outro modo, de um modo já celeste, por antecipação, no pão e no vinho repartidos e abençoados por ele. Nenhuma confusão dos dois estados é possível. Sobre o plano eucarístico, a ascensão abole a presença terrestre, e a história não possibilita senão a presença litúrgica ${ }^{26}$.
\end{abstract}

Depois da ascensão, o corpo transfigurado do Cristo não está mais submetido às leis de espaço e de tempo, mas pode manifestar-se em qualquer lugar, conforme sua vontade e estado teândrico, pois "todo poder me foi dado no céu e na terra" (Mt 28,18).

Se o ícone é exposto à veneração dos fiéis, a eucaristia é destinada a ser consumida. A finalidade da presença real de Cristo na eucaristia é a sua

${ }^{23}$ PEO 73-74; Ort 246, citando NICOLAU CABÁSILAS, Sacrae Liturgiae. Interpretatio 32,15: SC 4bis 206-207 [grifos do autor].

${ }^{24}$ Cf. PEO 74; Ort. 246.

25 "Eucharistie, mystère de l'Église", art. cit., p. 58.

${ }^{26}$ Idem, p. 60 [grifos do autor]. 
união com a assembléia reunida, cujo momento ápice é o comer e o beber os dons consagrados. A iconografia permite explicitar a invisibilidade da conversão eucarística. A metabolé exclui qualquer possibilidade de semelhança, pois a presença do Cristo na eucaristia não tem imagem. Não existe nada na natureza que se assemelhe ao que ocorre na conversão das espécies. Na crítica que faz ao movimento iconoclasta em relação à lei da identidade (os iconoclastas consideram a eucaristia a imagem do Cristo porque é consubstancial a ele), o nosso autor, em fidelidade aos cânones da Igreja que interditam toda a visão do Cristo na eucaristia por não se tratar de ícone, e sim de refeição, escreve:

O milagre da metabolé realiza-se sem nenhuma semelhança. Toda a visão da "carne" no cálice é severamente interditada pelos cânones e toda "aparição" deste gênero é considerada como tentação contra a natureza. Com efeito, o Verbo "enipostasia" apropria-se das espécies eucarísticas, integraas em seu corpo espiritual: "Este pão é o Corpo do Cristo", mas esta identidade substancial esconde a presença eucarística do Cristo, não sob o véu inerente a todo o mistério, e sim porque esta presença, não sendo visual, é sem imagem. O visível (o pão) é sempre afirmado idêntico ao invisível (o corpo celeste), mas a operação não deixa lugar algum à visão. A eucaristia não pode de forma alguma servir de ícone porque ela é unicamente a "Refeição do Senhor" que deve ser consumida e não contemplada ${ }^{27}$.

Evdokimov reconhece que há uma dificuldade, no Oriente, em relação à presença eucarística do Cristo, dificuldade essa que se apresenta como uma espécie de "duplicação do mistério": de um lado, a presença eucarística de Cristo está submetida ao mandato da consumição, de outro lado, a mesma presença força de alguma maneira o culto de adoração extralitúrgica. A Igreja Ortodoxa não expõe a hóstia consagrada para ser venerada ou adorada, como faz o Ocidente, mesmo fora da liturgia eucarística, através da Adoração ao Santíssimo ou da Procissão de Corpus Christi, mas conserva os dons exclusivamente para a consumição durante a liturgia eucarística, ou para serem levados aos doentes. A ação de levar a comunhão aos doentes é compreendida como extensão da liturgia eucarística. A adoração dos dons seria uma delimitação da presença do Cristo, contradizendo a ascensão. O que se adora é a presença do Espírito que manifesta o Cristo através dos dons santificados:

A adoração dos dons coisifica a manifestação do celeste e contradiz a Ascensão [...]. A adoração no decurso da liturgia é uma parte integrante da adoração litúrgica do mistério do Cristo. Prosterna-se não diante dos dons, e sim diante do Espírito nos dons, diante da vinda litúrgica do Cristo que o Espírito manifesta e que não tem mais a mesma realidade fora da liturgia ${ }^{28}$.

${ }^{27}$ L'art de l'icône: théologie de la beauté, 2 ed., Paris: Desclée de Brouwer, 1970, p. 168 [grifos do autor].

${ }^{28}$ Ort 247. 


\section{c) Crítica às doutrinas ocidentais da eucaristia}

O interesse de Evdokimov não foi apenas uma tentativa de explicitação deste mistério em âmbito ortodoxo, defrontou-se também com as doutrinas ocidentais. Reconhece que até o século IX não havia nenhuma questão em relação ao mistério da eucaristia, considerado o respeito e a veneração com que era tratada. A primeira vez que, no Ocidente, aparece a questão do quê ou do como, é no período que vai do séc. IX ao séc. XI, momento em que o verbo ser adquire o sentido de significar. O verbo significar, aplicado ao mistério eucarístico, nunca foi aceito pela Igreja Ortodoxa, e nem mesmo chegou a ser considerado como termo substitutivo do verbo ser:

A Igreja Ortodoxa [...] mantendo-se firmemente diante do mistério, afirma a identidade que resplandece: "Isto é meu corpo" e a aceita enquanto milagre inefável do amor divino ${ }^{29}$. $\mathrm{O}$ milagre da identidade é objetivo mesmo fora da consumição ${ }^{30}$.

Ao defrontar-se com as doutrinas ocidentais concernentes à eucaristia, Evdokimov observa que essas padecem de um certo "imanentismo cosmológico", que corre o risco de dar uma visão fisicista do mistério. Enquanto o Ocidente tenta explicar o que se realiza na consagração das espécies eucarísticas, o Oriente prefere não discutir nem especular a respeito, pois "há aí qualquer coisa de infinitamente maior do que uma simples mutação físi$\mathrm{Ca}^{\prime \prime 31}$. Conseqüentemente, haverá atitudes e posições teológicas diferentes entre Oriente e Ocidente, condicionadas pela diferença dos pressupostos.

A doutrina da transubstanciação e a doutrina da consubstanciação, na visão de nosso autor, "dogmatizam uma concepção filosófica das relações entre a substância e os acidentes" ${ }^{\prime \prime 2}$ : a conversão eucarística estaria, deste modo, na união ou ligação dos acidentes à substância, e na penetração da substância nos acidentes. O Cristo total (Christus totus et integer), sem deixar o céu, estaria ao mesmo tempo na terra para constituir a substância eucarística (onipresença). Estas doutrinas se assemelham, além disso acabam negando a verdade da Ascensão.

Do ponto de vista do corpo celeste de Cristo, transubstanciação e companação [companation] são apenas variantes de uma mesma coisa: a presença substancial do Cristo nas [dans] e sob [sous] as espécies do pão (in pane, sub pane, cum pane), ou sob [sous] os acidentes ou formas de pão. Mas uma coisa é o metabolismo do pão em carne celeste para ser consumido, e totalmente outra coisa é a presença do Cristo nas espécies, portanto, a sua descida na terra, de onde a conseqüência lógica: o culto de adoração da

${ }^{29}$ Ort 245.

30 "L'esprit de la religion orthodoxe", in L. FEBRE (éd.), Encyclopédie française v. 19 (1957) 19.50.15-19.52.30, aqui pp. 19.52.2.

${ }^{31}$ Ibidem 59.

${ }^{32}$ Ort 246. 
presença terrestre, física do Cristo, e por isso, a negação da ascensão... o corpo celeste não está sob [sous], com [avec], nem no [dans] pão (consubstanciação), nem no lugar do pão, mas é o pão: "Isto mesmo é minha carne" ${ }^{\prime \prime 3}$.

Será correto colocar a realidade transcendente da humanidade transfigurada do celeste e a realidade cósmica dos dons eucarísticos no mesmo plano ontológico, submetendo-as às mesmas leis que regem as relações entre substância e acidentes? Segundo Evdokimov, não, pois, a condição teândrico-celeste de Cristo não é regida pelas leis cósmicas, e sim pela lei da assimilação do material pelo espiritual:

\begin{abstract}
"À direita do Pai" não é um lugar, mas um símbolo da proximidade [...] "Celeste" não é uma noção cosmológica; o estado "celeste" da humanidade do Cristo é um transcensus que nos interdita de lhe aplicar a ontologia cósmica e suas leis. Esse estado não é de forma alguma uma desencarnação, e sim uma desmaterialização. Segundo os Padres, depois da queda, a matéria é uma condensação, uma espessura densa [épaississement] do espiritual, por isso, mesmo depois da queda, "nas coisas sensíveis", diz João Crisóstomo, "tudo é inteligível", a assunção do sensível no inteligível é normativa ${ }^{34}$.
\end{abstract}

Freqüentemente chamada "espiritualista", a doutrina eucarística de Calvino concebe a presença de Cristo na eucaristia graças à intervenção do Espírito Santo (in virtute Spiritus Sancti) e se opõe à doutrina luterana da ubiqüidade do Corpo do Cristo. O Cristo encontra-se no céu, e é o Espírito quem realiza a "conjunção" entre o seu Corpo e os sinais sacramentais, agindo como uma espécie de canal ou conduto através do qual o Cristo desce no mundo. Para Calvino, o poder do Espírito, invocado na epiclese, eleva o fiel ao céu e quando o fiel consome as espécies consagradas, realiza-se a comunhão com o corpo e sangue do Cristo celeste. Porém, tanto Calvino quanto Lutero priorizam a mensagem kerigmática das palavras da instituição e o aspecto subjetivo da salvação em detrimento do aspecto objetivo do sacramento e da consagração dos elementos eucarísticos. Ambos não suprimem os dados objetivos do mistério, mas priorizam o aspecto subjetivo da salvação, por intermédio da fé do comungante. Desse modo, mesmo acentuando a epiclese sobre os fiéis, os reformadores "desviam a atenção em relação à consagração dos elementos, o que parece fazer da fé a condição da presença do Cristo e submetem esta presença à medida da fé do homem"35.

A utilização de conceitos aplicados ao mistério eucarístico como "transfinalização" e "transignificação" são uma tentativa válida para expressar a presença real e o efeito unitivo contidos e comunicados nas espé-

${ }^{33}$ Ort 246-247.

34 "Eucharistie, mystère de l'Église", art. cit., p. 57, citando JOÃO CRISÓSTOMO, In Matthaeum homilia 84, 4: PG 58, 743.

35 "Eucharistie, mystère de l'Église", art. cit., p. 56. 
cies eucarísticas, porém qualquer termo que se utilize para expressar o mistério eucarístico deve necessariamente salvaguardar a idéia de uma conversão ontológica ${ }^{36}$.

\section{Aprendendo de Evdokimov}

\subsection{Epiclese e momento da consagração}

Fiel ao princípio da necessidade da intervenção hipostática do Espírito para a realização de toda ação espiritual manifestadora de Cristo, Evdokimov atribui a consagração à epiclese. E, ao evitar a tentativa de cronometrar $\mathrm{O}$ instante da consagração, mantém-se fiel ao espírito da liturgia que compreende a celebração eucarística como um conjunto unitário de ritos, mediante os quais a assembléia, por intermédio de seu presidente, suplica a Deus o envio do Espírito a fim de manifestar, num renovado e contínuo Pentecostes, a presença sacramental de Cristo. Tais afirmações acerca da eficácia consecratória e o momento da consagração têm clara origem na relação de unidade entre teologia e liturgia, entre lex orandi e lex credendi.

Contudo, se procedermos a um confronto dessas afirmações com a posição da teologia latina até às vésperas do Concílio Vaticano II, estaremos diante da impossibilidade de um consenso teológico. Por outro lado, na Igreja Católica Romana, o retorno à tradição primitiva a aproximou da Igreja Ortodoxa.

\section{a) Evolução da posição católica}

A posição latina se caracteriza pelo fato de atribuir eficácia consecratória exclusiva às palavras da instituição eucarística, cuja recitação pelo presidente da celebração define o instante preciso da transubstanciação, independentemente da epiclese. O problema da epiclese, em âmbito magisterial, só vai aparecer no século XIV. Até então não se percebe contradição entre o pedido de intervenção do Espírito Santo e as palavras da instituição para a realização do sacramento. O Concílio de Lyon (1274), convocado para reunir as duas Igrejas, não tratou da questão. Nem mesmo antes, em 1054, quando ocorreu a separação das duas Igrejas, a questão sequer foi levantada por gregos ou latinos. A questão da epiclese foi tratada no Concílio de Florença (1439-1445). Na ocasião, a Igreja latina ratificou a sua posição afirmando o valor consecratório das palavras da instituição. Os gregos, evidentemente, não aprovaram essa decisão da Igreja Romana. As intervenções magisteriais posteriores, pelo menos até o Concílio Vaticano II, seguirão reafirmando a mesma doutrina.

\footnotetext{
${ }^{36}$ Ibidem, p. 55.
} 
A evolução de perspectiva com relação à teologia eucarística se fez notar fortemente a partir do Concílio Vaticano II. Nessa ocasião, a Igreja Católica Romana iniciou um processo de reconhecimento e valorização do patrimônio litúrgico, teológico e espiritual das Igrejas do Oriente. O resultado veio em seguida e pôde ser percebido na lex orandi. Na liturgia latina, passou-se a ressaltar a importância da epiclese na liturgia sacramental, sobretudo, a eucarística. Todas as novas Orações eucarísticas, introduzidas no Missal Romano, contêm uma epiclese pneumatológica: o sacerdote pede ao Pai que, por intermédio do Filho, envie o Espírito Santo para a transformação das oferendas e para aplicação dos benefícios da eucaristia aos comungantes. Tratase das duas epicleses, a da consagração e a da comunhão, com a narrativa da instituição eucarística e a anamnese entre a primeira e a segunda.

Outro indício claro de sensibilidade pela teologia e liturgia orientais pode ser percebida no novo Catecismo da Igreja Católica (1982). Situando a eucaristia no contexto da economia salvífica, o texto catequético não se limita a mencionar a epiclese pneumatológica explícita utilizada pela Igreja, como fazem as Igrejas Orientais, mas vai mais longe - resultado provável do diálogo entre representantes das duas Igrejas realizado nas décadas de $1980-1990^{37}$-, ao afirmar o valor consecratório, seja das palavras da instituição da eucaristia, seja da epiclese, manifestando, assim, um equilíbrio em relação ao que denominamos eficácia consecratória:

Encontram-se no cerne da celebração da Eucaristia o pão e o vinho, os quais, pelas palavras de Cristo e pela invocação do Espírito Santo, se tornam o Corpo e o Sangue de Cristo $^{38}$.

O sacramento eucarístico recebe, no novo Catecismo, um tratamento desde uma perspectiva dinâmico-celebrativa. A epiclese é situada no conjunto da anáfora, seguindo ao prefácio e antecedendo à narrativa da instituição eucarística:

Na epiclese ela [Igreja] pede ao Pai que envie o seu Espírito Santo (ou o poder de sua bênção) sobre o pão e o vinho, para que se tornem, por seu poder, o Corpo e o Sangue de Jesus Cristo, e para que aqueles que tomarem parte na Eucaristia sejam um só corpo e um só Espírito (certas tradições litúrgicas colocam a epiclese depois da anamnese) $)^{39}$.

O novo Catecismo evita utilizar a linguagem da cronometria para definir o momento em que se realiza a presença real de Cristo na eucaristia. Em

37 As Sessões Plenárias aconteceram em Patmos-Rhodes (1980), Munique, Alemanha (1982), Creta, Grécia (1984), Bari, Itália (1986 e 1987), Valamo, Finlândia (1988), Freising, Alemanha (1990) e Balamand, Líbano (1993). Cf. A. GONZÁLEZ MONTES, Las Iglesias Orientales, Madrid: Editorial Catolica [BAC], 2000, p. 347-594; G. BRUNI, Quale ecclesiologia? Cattolicesimo e Ortodossia a confronto: il dialogo ufficiale, Milano: Paoline, 1999, pp. 61-341.

${ }^{38}$ Catecismo 1333; cf. 1353, 1357-1358, 1375.

${ }^{39}$ Ibidem 1353 - [grifos dos autores]. 
respeito à dimensão mistérica da presença de Cristo no sacramento eucarístico, a afirmação do texto pode-se dizer sóbria e breve, sem alusão a fórmulas litúrgicas que possam condicionar o momento da consagração: Salvaguarda, assim, a unidade da anáfora, que é, ao mesmo tempo, doxológica (ação de graças) e consecratória.

O último e mais recente passo dado pela Igreja Católica Romana foi o reconhecimento da validade da eucaristia celebrada com a anáfora de Addai e Mari, uma das três anáforas atualmente em uso pela Igreja Assíria do Oriente. A singularidade dessa anáfora é a ausência da narrativa institucional e das palavras da instituição eucarística de forma literal, como constam nas narrativas bíblicas (cf. Mt 26, 20.26-29; Mc 14, 17.22-25; Lc 22, 14-20 e 1Cor 11, 23-25). Esse avanço foi ocasionado por razões doutrinais e pela necessidade de ordem pastoral e ecumênica em conseqüência do diálogo ecumênico iniciado há alguns anos entre a Igreja Católica Romana e a Igreja Assíria do Oriente ${ }^{40}$.

A Igreja Católica reconhece a validade dessa anáfora pelo fato de que a sua elaboração e a sua utilização manifestam a clara intenção da Igreja de celebrar a eucaristia em continuidade com a última Ceia. A sua validade nunca foi posta em questão por nenhuma Igreja, quer do Oriente, quer do Ocidente. Em segundo lugar, a sua validade deve-se ao fato de que "as palavras da instituição eucarística estão, de fato, presentes na anáfora de Addai e Mari, não de modo coerente e ad litteram, mas de modo eucológico e disseminado, isto é, estão integradas em orações sucessivas de ação de graças, louvor e intercessões" ${ }^{\prime 4}$.

Muito embora o alcance da nota concernente ao uso da anáfora de Addai e Mari seja restrito a casos excepcionais e de necessidade, a nota tem um grande valor para o diálogo ecumênico e para a teologia litúrgica ${ }^{42}$. A tradição siro-oriental não é mais submetida aos cânones latinos. Ao veicular uma nova maneira de compreender a oração eucarística, não como mimesis sacrifical (própria da visão ocidental, centralizada na narrativa da instituição), a anáfora arcaica de Addai e Mari possibilita uma redescoberta da centralidade da oferenda de ação de graças propriamente dita no interior da anáfora, a qual dá pleno sentido à noção de sacrifício de louvor.

Reconhece-se, assim, o esforço pós-conciliar da Igreja Católica Romana em reconhecer e valorizar a epiclese, seja pela via da aproximação com as

${ }^{40}$ Cf. ACTES DU SAINT-SIÈGE, “Admission à l'Eucharistie entre l'Église chaldéenne et l'Église assyrienne d'Orient: note et orientations du Conseil pontifical pour la promotion de l'Unité des chrétiens", La Documentation Catholique no 2265 (2002) 213-214.

${ }^{41}$ Ibidem 214. C. Giraudo vê nesta anáfora uma confirmação de sua tese de que a narração da instituição só num segundo momento foi inserida na anáfora. Cf. C. GIRAUDO, "Num só corpo": Tratado mistagógico sobre a eucaristia, São Paulo: Loyola, 2003, pp. 206-209, 249-250.

${ }^{42}$ S. MATTHIEU, "Une avancée oecuménique et liturgique: la note romaine concernant l'anaphore d'Addaï et Mari”, La Maison-Dieu nº 233 (2003) 137-154. 
Igrejas Orientais, seja pela recuperação da tradição mais primitiva da Igreja do primeiro milênio. A posição da Igreja Católica Romana evoluiu não só no sentido de não contrapor-se à crença na eficácia da epiclese da Igreja Ortodoxa, mas inclusive de integrá-la em seu patrimônio litúrgico e magisterial. A superação da utilização da linguagem hilemórfica para explicar os sacramentos, e, em especial a eucaristia, e o caminho percorrido pelo estudo da lex orandi parecem ter sido a melhor escola de aprendizagem para redimensionar o sacramento eucarístico desde a perspectiva dinâmico-celebrativa e desde a economia salvífica. Acrescente-se que, por respeito ao mistério eucarístico e à unidade da anáfora, a Igreja Católica Romana evita agora circunscrever o momento em que se realiza a transubstanciação.

\section{b) Diálogo ecumênico e correção de rota da Igreja Católica}

Em face às posições (aparentemente) irreconciliáveis entre Evdokimov e a Igreja Latina, o apelo aos diálogos ecumênicos oficiais permitem perceber a possibilidade de conciliação entre posições tão distintas.

Os encontros de diálogo ecumênico entre a Igreja Católica e a Igreja Ortodoxa de tradição bizantina iniciaram-se na década de $60^{43}$. O primeiro documento de acordo ecumênico entre as duas Igrejas, aprovado por unanimidade na Segunda Sessão Plenária da Comissão Mista Internacional do Diálogo Teológico, em Munique, Alemanha (de 30 de junho a 06 de julho de 1982), intitulase $O$ mistério da Igreja e da Eucarista à luz da Trindade Santa ${ }^{44}$. A Comissão mista que elaborou o documento teve a clara preocupação de mostrar o que une as duas Igrejas, considerando-o como primeira etapa no diálogo teológico entre católicos e ortodoxos. O diálogo entabulou-se no plano da tradição.

A epiclese, uma questão outrora controvertida e sofrida, é apresentada no mencionado documento com vontade clara de expressar a doutrina comum das duas Igrejas, em um clima que foi favorecido no período pósconciliar. O documento deixa transparecer que a questão foi discutida e solucionada. No que se refere à eficácia consecratória, o documento une as duas tradições, a oriental e a ocidental:

[...] o mistério eucarístico realiza-se na oração que une as palavras, pelas quais a Palavra feita carne instituiu o sacramento, e a epiclese, na qual a

${ }^{43}$ Para os encontros da fase preparatória, a elaboração do método e os objetivos do diálogo entre os representantes das duas Igrejas, cf. G. BRUNO, op. cit., pp. 13-64; P. RODRÍGUEZ, "El diálogo teológico entre la Iglesia Católica y la Iglesia Ortodoxa: I. De los inícios a la Relación de Bari (1962-1987)", in A. GONZÁLEZ MONTES, op. cit., pp. 347-393; D. PAPANDREOU, "Les dialogues bilateraux de l'Église orthodoxe avec les autres Communios chrétiens, Irénikon $\mathrm{n}^{\circ} 4$ (1982) 451-470, aqui pp. 456-458; A. DE HALLEUX, "Inauguration du dialogue théologique officiel entre les Églises catholique et orthodoxe Revue Théologique de Louvain n 3 (1980) 394-398.

${ }^{44} \mathrm{Cf}$. "LE MYSTÈRE de l'Église et de l'Eucharistie à la lumière de la Sainte Trinité: document de la commission mixte catholique romaine-orthodoxe. Munich, 30/06-06/071982", La Documentation Catholique n 1838 (1982) 941-945 [= Munique]. 
Igreja, movida pela fé, suplica ao Pai, através do Filho, a fim de enviar o Espírito Santo para que, na única oblação do Filho encarnado, tudo seja consumado na unidade ${ }^{45}$.

O documento é claro e inclui a tradição católica e a tradição ortodoxa: a primeira, que atribui valor consecratório às palavras da instituição e, mais recentemente, integrou a epiclese pneumatológica na realização do sacramento; e a segunda, que atribui valor consecratório à epiclese. Sob este prisma, o nosso autor também está incluído nessa conciliação ecumênica. O motivo que levou os membros das respectivas comissões a encontrar uma conciliação foi evitar definir ou concentrar-se no problema do momento da consagração, muito embora não seja este o pano de fundo do problema que divide as duas Igrejas, como também utilizar uma linguagem não polêmica, e sim uma linguagem comum, a da tradição bíblicopatrístico-litúrgica, que favorecesse o intercâmbio de idéias. Não é por acaso que Evdokimov se move nesse âmbito lingüístico.

Se tomarmos a segunda afirmação ou linha de pensamento de Evdokimov de que toda a celebração eucarística tem um caráter epiclético - o documento de Munique contempla plenamente o pensamento de nosso autor. Na primeira parte do documento, quando trata da relação entre o Filho e o Espírito na economia da salvação e, de modo especial, no sacramento eucarístico, diz:

O Espírito transforma os dons sagrados no corpo e no sangue do Cristo (metabolé), para que se cumpra o crescimento do Corpo que é a Igreja. Neste sentido, a celebração inteira é uma epiclese, que se explicita mais em certos momentos. A Igreja está perpetuamente em estado de epiclese ${ }^{46}$.

A afirmação de que "a celebração inteira é uma epiclese" ressalta a dependência da Igreja em relação ao Espírito Santo para a realização do sacramento eucarístico. A ação prévia do Espírito é necessária para a manifestação sacramental de Cristo.

Os documentos oficiais de acordos ecumênicos posteriores retomarão ainda que brevemente o tema da eficácia consecratória, mais especificamente, a alusão à ação do Espírito invocado na epiclese. A afirmação de que a transformação dos dons é realizada pelo Espírito reaparecerá de forma alusiva, indireta, no documento de $\mathrm{Bari}^{47}$, e de forma direta no documento de Valamo $^{48}$. A transformação dos dons eucarísticos pelo Espírito não é

\footnotetext{
${ }^{45}$ Munique I, 6, c.

${ }^{46}$ Munique I, 5, c.

${ }^{47}$ COMMISSION INTERNATIONALE CATHOLIQUE-ORTHODOXE, "Foi, sacrementes et unité de l'Église. (Cassano delle Murge, Bari, 16 juin 1987)”, Irénikon nº 3 (1987) 336349 [= Bari].

${ }^{48}$ COMMISSION INTERNATIONALE CATHOLIQUE-ORTHODOXE, "Le Sacrement de l'Ordre dans la structure sacramentelle de l'Église, en particulier l'importance de la sucession apostolique pour la sanctification et l'unité du peuple de Dieu. Valamo, Finlande, 26 juin 1988". Irénikon n 3 (1988) 347-359 [= Valamo].
} 
uma afirmação que tem a pretensão de polemizar contra a doutrina católica tradicional que conferia valor consecratório às palavras da instituição, e sim uma afirmação de que a eucaristia se realiza mediante a condição suplicante da Igreja, condição sob a qual estão o sacerdote que implora a descida do Espírito Santo em nome da assembléia reunida e as palavras da instituição que ele recita. No "estado epiclético" da celebração eucarística, nada é subtraído à súplica. Obviamente o documento quis manifestar com isso um grande respeito à liturgia eucarística de ambas as tradições.

Retomemos o pensamento de nosso autor, onde se pode perceber o equilíbrio entre epiclese e anamnese (a narrativa da instituição) no estado epiclético da Igreja:

Para que a palavra do Cristo, memorializada [mémorisée] pelo sacerdote, se cumpra e adquira eficácia divina, o sacerdote invoca o Espírito Santo na epiclese. Das palavras da anamnese pronunciadas pelo sacerdote, "tendo tomado o pão ... entregou-o aos seus discípulos dizendo... isto é meu corpo", o Espírito faz anamnese epifânica, manifesta a intervenção do Cristo identificando as palavras pronunciadas com suas próprias palavras: é o milagre da metábole $e^{49}$.

Oriente e Ocidente estão de acordo em reconhecer que a conversão eucarística é, como a encarnação, obra do Espírito Santo. No texto citado de nosso autor, parece pressentir-se não uma contradição entre palavras da instituição e epiclese, mas complementaridade. A ação do Espírito na eucaristia, assim como nos outros sacramentos, exige um sinal visível. Epiclese e anamnese são igualmente necessárias no sacramento eucarístico, o que evidencia a obra conjunta do Filho e do Espírito na eucaristia.

O permanente "estado epiclético" da Igreja, de modo especial durante a liturgia eucarística, enfatiza a realidade salvífica no tempus Ecclesiae. A Igreja é o lugar da presença e da atuação do Espírito, enviado pelo Cristo glorificado, conforme sua promessa, antes da ascensão. No diálogo com a Ortodoxia, pensa P. Rodríguez, exige-se o esforço da parte católica em não considerar, na anáfora, a narrativa institucional e as palavras da epiclese como momentos sucessivos, pois, no texto de acordo ecumênico de Munique, se se segue a literalidade do texto, a perspectiva do ou-ou continuará latente. Tanto a epiclese quanto as palavras da instituição são momentos de súplica intensa pela descida do Espírito.

Evdokimov ensina a atitude apofática face ao mistério: não se podem aplicar categorias de espaço ou de tempo físico a uma realidade que é transcendente. Isso ajuda a superar a idéia de automatismo sacramental e de quase magia aplicada às palavras utilizadas na liturgia. $O$ tempo da consagração é um tempo sacramental que extrapola a idéia física de tempo de que

${ }^{49}$ PEO 81. 
dispomos. Conseqüentemente, não se trata de ver na epiclese e nas palavras da instituição duas consagrações sucessivas e distintas no tempo. A fixação de uma fórmula única, como fizeram gregos e latinos, é um erro.

Sintetizando: a) a recuperação do caráter epiclético da liturgia, aspecto evidenciado pelo nosso autor e pelo documento de Munique, coloca tanto a epiclese quanto as palavras da instituição eucarística, sob o âmbito suplicante da liturgia; b) em decorrência do caráter epiclético da liturgia, não se pode determinar o instante da consagração, ênfase dada pelo nosso autor e pressuposta no documento de Munique (e com ele, no novo Catecismo). Tratando-se de um tempo sacramental, extrapola a possibilidade de aplicar categorias de tempo físico a uma realidade que é fundamentalmente mistérica, e permite superar a concepção de automatismo sacramental. As afirmações da lex orandi são compreendidas desde seu lugar de origem, de modo que não se rompe a unidade entre a lex orandi e a lex credendi. c) Ao atribuir a eficácia consecratória às palavras da instituição eucarística e à epiclese, o documento de Munique uniu a tradição católica e ortodoxa, e, por extensão, confirmou o nosso autor também.

\subsection{Epiclese e modo de consagração}

A compreensão da conversão eucarística, designada tradicionalmente pelo termo metabolé, permaneceu inalterável na Igreja Ortodoxa desde o tempo patrístico até os dias atuais. Os autores ortodoxos atuais, entre os quais Evdokimov, evitam pressupostos filosóficos e se atêm aos dados bíblicos, patrísticos e litúrgicos. Já o Ocidente cristão, se permaneceu com a mesma linguagem pelo menos até o final do primeiro milênio, a partir de então foi levado progressivamente a identificar-se, mediante reflexão da escolástica, com o termo transubstanciação.

O procedimento reflexivo de Evdokimov a propósito da atitude de reserva (apofática) quanto ao modo de consagração das oferendas (cf. item 1.3), pode ser resumido nas seguintes afirmações: a) Fiel à Ortodoxia e aos Padres, mais do que explicar, Evdokimov limita-se simplesmente a confessar a misteriosa transformação das espécies eucarísticas através do termo comum ao Oriente: a metabolé; o modo de consagração, objeto exclusivo da fé, não é suscetível de investigação do tipo fisicista ou filosófica. b) $\mathrm{O}$ ponto de partida intelectivo do mistério eucarístico é cristológico. A inteligibilidade do que ocorre na consagração é regida pelo dogma cristológico calcedônico: união do divino e do humano, "sem separação, sem confusão" (teandrismo). O estado teândrico do Cristo glorificado condiciona a compreensão do modo da consagração. c) A finalidade da presença real de Cristo nas oferendas consagradas é a consumição, diversamente do ícone que é exposto para a veneração dos fiéis. d) As críticas às doutrinas ocidentais da eucaristia visam sobretudo o ponto de partida destas doutrinas, a filosofia, pois tais doutrinas veiculam um "certo imanentismo cosmológico" favorecendo atitu- 
des e posturas teológicas suspeitas. A humanidade glorificada de Cristo não pode ser submetida às leis cósmicas (crítica aos católicos e luteranos), como também a presença real de Cristo nas espécies consagradas não pode ser submetida à medida da fé da assembléia (crítica aos reformadores). Qualquer termo ou categoria utilizada para explicar o mistério da consagração deve salvaguardar a idéia da conversão ontológica. O que a epiclese realiza transcende a razão científica, situa-se no plano da fé (metafísico), o que, por sua vez, não deixa de ser real e objetivo.

\title{
a) Sobriedade da terminologia patrística
}

Evdokimov é claramente patrístico no que concerne à compreensão do modo de conversão das oferendas. A metabolé realiza a identificação total das oblações com o corpo do Senhor. Para fundamentar essa identificação,

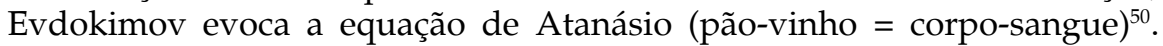
Muito embora não cite a fonte, é provável que esteja se referindo a um extrato de sermão atribuído a Atanásio:

\begin{abstract}
Antes que as orações e invocações tenham sido feitas, não são senão pão e um cálice. Porém, depois que as grandes e maravilhosas orações foram ditas, o pão torna-se o corpo e o vinho torna-se o sangue de nosso Senhor Jesus Cristo [...]. No momento em que se faz subir a Deus as grandes orações e as santas súplicas, o Verbo desce sobre o pão e o cálice e o pão tornase seu corpo $^{51}$.
\end{abstract}

Os Padres eram extremamente sóbrios ao falar da transformação das espécies no sacramento eucarístico. Para isso, utilizam o termo metabolé e similares. Em uma de suas homilias catequéticas, Cirilo de Jerusalém compara a transformação (metabálein) da água em vinho, nas bodas de Caná, com a conversão eucarística. Se Cristo transformou a água em vinho, não há razão para duvidar que ocorra um milagre semelhante no banquete eucarístico ${ }^{52}$. Cirilo diz ainda que Deus manda seu Espírito sobre as oferendas, tornando-as corpo e sangue de Cristo, porque tudo o que o Espírito toca é santificado e transformado (metablébetai) ${ }^{53}$. As palavras da última ceia: "Isto é meu corpo, isto é meu sangue", indicam que os objetos visíveis [pão e vinho] foram transformados (metapoieisthai) no corpo e sangue do Senhor pelo poder indizível de Deus ${ }^{54}$. Em outra passagem, observa que Deus "infunde um poder vivificante na oferenda e a transmuta (methístesin autá) na virtude da própria carne" ${ }^{\prime \prime 55}$.

Gregório de Nissa, o mais especulativo dos Padres capadócios, retoma a idéia da transformação. Na conversão eucarística, pensa Gregório de Nissa, a "na-

${ }^{50}$ Cf. PEO 73.

${ }^{51}$ ATANÁSIO DE ALEXANDRIA, Fragm., Ex sermone ad baptizandos: PG 26, 1325.

${ }^{52}$ Cf. CIRILO DE JERUSALÉM, Catechesis mystagogica 4, 2: SC 126, 136.

${ }^{53}$ Cf. CIRILO DE JERUSALÉM, Catechesis mystagogica 5, 7: SC 126, 154.

${ }^{54}$ CIRILO DE ALEXANDRIA, Comentariorum in Mathaeum 26, 27: PG 72, 451.

${ }^{55}$ CIRILO DE ALEXANDRIA, Explanatio in Lucae Evangelium 22,19: PG 72, 908. 
tureza dos objetos visíveis" (pão e vinho) sofrem uma espécie de transelementação (metastoicheiósas) ${ }^{56}$. Este termo grego é de difícil tradução nas línguas modernas, e não é considerado ainda uma explicação propriamente dita para a conversão eucarística. Utilizando este termo, Gregório de Nissa parece pensar em uma alteração na relação dos elementos constitutivos (stoicheia) do pão e do vinho, em conseqüência da qual estes adquirem a "forma" (eidos) do corpo e do sangue do Senhor e as propriedades correspondentes. Embora alguns autores tentassem seguir Gregório de Nissa na tentativa de explicar o modo de mutação das oferendas, contudo, desde então, a linguagem da metabolé (transformação, mudança) tornou-se comum ao Oriente.

Para João Crisóstomo, na celebração eucarística, os elementos (pão e vinho) sofrem uma mutação, são definidos como trans-plasmados (metarrythmizein) e transformados (metaskeyázein) ${ }^{57}$.

Os teólogos orientais, fiéis à tradição bizantina, na defesa da doutrina da presença real, nunca utilizam o termo essência, símbolo ou imagem para explicar a conversão eucarística. Consideram o termo transubstanciação impróprio para o mistério eucarístico. Esse termo só vai aparecer no Oriente a partir do século XIII por influência dos latinóforos, mas não chega a se impor ${ }^{58}$.

A reserva dos Padres em relação à conversão eucarística reflete-se ainda mais forte na tradição siro-cristã, a ponto de evitar-se o uso do termo conversão em favor de outro: per unionem cum Spiritu [por união com o Espírito] ${ }^{59}$. João Damasceno, que apresenta uma síntese condensada dos Padres gregos, afirma que o pão e o vinho são transformados de forma sobrenatural (hyperphyós metapoioúntai) ${ }^{60}$.

\section{b) Sobriedade da terminologia litúrgica}

A mesma reserva dos Padres em relação ao que ocorre na conversão eucarística, simultânea à afirmação sem hesitação da presença real, será mantida na linguagem das anáforas orientais e ocidentais.

Em ambiente ocidental, as epicleses galicanas e hispânicas também utilizam uma terminologia que evoca a idéia de conversão ou mudança real, como, por exemplo, na missa gótica: coelesti permutatione [mudança celeste], ou ainda, esta fórmula tipicamente mozarábica: faciat plenisque tui corporis sanguinisque conformia [faça conforme à plenitude de teu corpo e sangue], ou esta outra: panem mutatum carne, poculum versum in

${ }^{56}$ Cf. GREGÓRIO DE NISSA, Oratio Catechetica 37: SC 453, 314.

${ }^{57}$ Cf. JOÃO CRISÓSTOMO, Homilia De proditione Iudae 1, 6: PG 49, 380; In Matthaeum homil. 2, 5: PG 57, 29.

${ }^{58}$ Cf. G. BRUNI, op. cit., 106, nota 29.

${ }^{59}$ Cf. P. L’HUILLIER, “Théologie de l'épiclèse", Verbum Caro n ${ }^{\circ} 56$ (1960) 307-327, aqui pp. 317-318.

${ }^{60}$ Cf. JOÃO DAMASCENDO, De fide orthodoxa 4, 13: PG 94, 1145-1149. 
sanguinem [pão transformado em carne, bebida convertida em sangue] ${ }^{61}$. Depois de suplicar a Deus para que aceite e santifique as oferendas, o cânon romano pede a transformação das mesmas no corpo e sangue do Senhor, através do verbo latino fazer: ut nobis Corpus et Sanguis fiat dilectissimi Filii tui, Domini nostri Iesu Christi [para que se torne <se faça> para nós o corpo e o sangue de teu diletíssimo Filho, nosso Senhor Jesus Cristo]. Os formulários epicléticos das novas anáforas ocidentais manterão a mesma sobriedade lingüística: suplica-se a Deus para que envie o Espírito Santo a fim de que as oferendas "se tornem o corpo e o sangue do Senhor".

O verbo faze (poíeson), com o qual se pede a transformação das oferendas, está presente também nas três anáforas bizantinas, atualmente em uso na Igreja Ortodoxa (a de Basílio, a de Crisóstomo e a de Tiago). Além de poíeson, o formulário epiclético da anáfora de João Crisóstomo utiliza o verbo grego transformando (metabalón) e a de Basílio utiliza o verbo grego manifeste (anadeíxai) ${ }^{62}$. Ao investigar a origem e a utilização do termo metabolé na liturgia bizantina, H. Paprocki considera-o inicialmente uma interpolação pelo simples fato de que nada acrescenta à epiclese, pois esta já contém o verbo faze (poíeson), cujo significado é o mesmo de transformar (metabolé) ${ }^{63}$.

No Tratado sobre o Espírito Santo, Basílio utiliza anadeíknymi no sentido de consagração: "Qual dos santos nos deixou por escrito as palavras da consagração (anadeíxei) do pão eucarístico e do cálice da bênção?" ${ }^{\prime 64}$. Muito embora o termo não pareça próprio para expressar a idéia de conversão das oferendas, está presente em várias anáforas antigas com o sentido explícito de transformação das oferendas, como também é utilizado para expressar a consagração ao ministério hierárquico e a transformação dos fiéis no decurso da liturgia.

Concluindo: a linguagem dos Padres e da lex orandi é muito sóbria quanto à conversão eucarística. Com a utilização dos verbos metabalón, poíesonfiat, anadeíxis e similares se quer expressar uma ação real sobre o pão e o vinho para transformá-los em algo totalmente diferente, mas cuja inteligibilidade só é acessível à fé, como também afirmar a identificação entre as oblações eucarísticas e o corpo do Senhor. Estes verbos representam, na verdade, mais uma profissão de fé ou reconhecimento do milagre eucarístico do que propriamente uma explicação. É justamente a esse nível de investigação que Evdokimov, nutrindo-se da inesgotável seiva patrística e litúrgica, se atém. Em seu procedimento apofático aplicado à doutrina eucarística, rediz a tradição comum ao Oriente e ao Ocidente do primeiro milênio.

${ }^{61}$ Cf. P. L'HUILLIER, "Théologie de l'épiclèse", art. cit., p. 318; J. PINELL, "Anámnesis y epíclesis en el antiguo rito galicano", Didaskalia n ${ }^{\circ} 4$ (1974) 3-130, aqui pp. 35-36.

${ }^{62}$ Cf. A. HÄNGGI; I. PAHL (ed.), Prex eucaristica: textus et variis liturgiis antiquioribus select, Fribourg: Universitaires, 1968, p. 226, 236, 250.

${ }^{63}$ Cf. H. PAPROCKI, Le mystère de l'eucharistie: genèse et interprétation de la liturgie eucharistique byzantine, Paris: Cerf, 1993, pp. 324-325.

${ }^{64}$ BASÍLIO DE CESARÉIA, De Spiritu Sancto 27, 66: SC 17bis, 480. 


\section{c) Reconhecimento ecumênico da provisoriedade da linguagem}

A partir do Concílio de Trento (1545-1563), a Igreja Católica reconheceu o termo técnico transubstantiatio como muito apto (aptissime), conveniente (convenienter) e apropriado (proprie $)^{65}$, mas não teve a intenção de propôlo como se fosse algo absoluto, porque reconhece a dificuldade da linguagem humana para traduzir o mistério da conversão das oferendas e da presença real do Cristo nas oferendas consagradas. A Igreja de tradição latina, favorecida pela visão jurídico-romana e, posteriormente, pelas influências da visão fisicista-germânica, não sustentou de modo geral uma atitude apofática face ao mistério eucarístico, como aconteceu com a Igreja de tradição grega ${ }^{66}$.

Se procedêssemos a um confronto da visão de Evdokimov com a teologia latina experimentaríamos certamente um desconforto. Não obstante as diferenças, há aspectos fundamentais comuns entre Evdokimov e a Igreja Católica: um e outro colocaram-se, em verdade, no plano da tradição. O que Evdokimov quer dizer através do termo metabolé, a Igreja Católica o diz através do termo transubstanciação: ambos afirmam claramente a conversão ontológica das oferendas e a presença real do Cristo nas oferendas consagradas. Católicos e ortodoxos não podem negar que o que vêem depois da consagração são as mesmas aparências do pão e do vinho, e o que ocorre na metabolé ou transubstanciação é de ordem ontológica e metafísica, por isso, inapreensível pela razão científica. Embora utilizando termos distintos, Evdokimov e o Concílio Tridentino expressam o que as Igrejas Ortodoxa e Católica sempre creram a partir das palavras de Jesus na ultima ceia sobre o pão e o vinho: "Isto é meu o corpo, isto é o meu sangue". Não obstante a diferença dos termos e do ponto de partida de um lado e de outro, o alcance do significado dos termos metabolé e transubstanciação é o mesmo:

Na verdade, este termo [transubstanciação], em razão da tecnicidade filosófica que o termo substância devia tomar posteriormente na escolástica, e que repugna a excelentes teólogos, não quer dizer outra coisa que o termo conversio utilizado por Ambrósio, que traduz o metabolé da tradição grega e pode ser considerado com direito como a mais simples expressão da fé da Igreja ${ }^{67}$.

Para salvaguardar o mistério da conversão eucarística e o mistério da presença real do Cristo nas oblatas consagradas, acordou-se entre ambas as

${ }^{65}$ DS 1642, 1652.

${ }^{66}$ Deve-se, no entanto, reconhecer que um dos limites da teologia evdokimoviana é achar que o termo transubstanciação seja uma tentativa de explicação filosófica do que ocorre na consagração eucarística. Evdokimov teria razão se todos os teólogos católicos assim o pensassem. Contudo, há quem pense que o termo apenas rediz o que a tradição sempre afirmou (cf. K. RAHNER, "La presencia de Cristo en el Sacramento de la Cena del Señor", in Idem, Escritos de Teologia, Madrid: Taurus Ediciones, 1961, v. 4. pp. 367-396; J. A. SAYES, La presencia real de Cristo en la eucaristia, Madrid: Editorial Catolica, 1976, pp. 171-176).

${ }^{67}$ J.-H. NICOLAS, Syntèse dogmatique: de la Trinité à la Trinité, 2. ed., Fribourg, Suisse: Universitaires; Paris: Beauchesne, 1986, p. 910. 
Igrejas, Católica e Ortodoxa, uma atitude apofática, no sentido de utilizar uma linguagem decididamente sóbria, apta às coisas da fé. A primeira e surpreendente constatação é que o documento ecumênico de Munique não contém o termo transubstanciação. As comissões que elaboraram e aprovaram o documento optaram por um termo que fosse demonstrativo de uma base lingüística comum para as Igrejas e que permaneceu até o início do segundo milênio cristão, antes da divisão das Igrejas. O termo escolhido deveria expressar familiaridade e proximidade com os dados bíblicos, patrísticos e litúrgicos. Partindo desses pressupostos, as respectivas comissões optaram pelo termo metabolé (transformação ou mudança). Na primeira parte, quando trata da missão conjunta do Filho e do Espírito na economia da salvação, o documento de Munique afirma com extrema sobriedade lingüística: " $\mathrm{O}$ Espírito transforma os dons sagrados no corpo e sangue do Cristo (metabolé), para que se cumpra o crescimento do corpo, que é a Igreja"68.

A terminologia sóbria é, contudo, de profundo significado. Ambas as Igrejas confessam que a transformação das oferendas é obra exclusiva do poder de Deus, mediante o seu Espírito. Não há explicitação quanto ao modo da transformação dos dons. O documento evita entrar em questões de ordem lingüística, limitando-se simplesmente a confessar a ação do Espírito nas oblatas em vista do crescimento da Igreja. Deve-se observar, porém, que o termo metabolé aparece entre parênteses. Utiliza-se no decurso da afirmação o equivalente transformar. É a primeira e única vez que o termo metabolé aparece no texto de Munique; nos outros documentos sequer é citado. $\mathrm{O}$ propósito da utilização de uma linguagem sóbria foi, a nosso ver, salvaguardar o caráter ontológico e metafísico da conversão eucarística, aspectos confessados e cridos nas duas Igrejas.

O documento de Munique salienta o silêncio dos evangelistas a respeito do como da consagração do pão e do vinho na última Ceia. Sempre reconhecendo a inseparabilidade do Filho e do Espírito na realização da missão redentora, o documento diz: "Se bem que os evangelistas, na narrativa da Ceia, silenciem sobre a ação do Espírito, ele, contudo, estava, mais do que nunca, unido ao Filho encarnado para o cumprimento da obra do Pai"69. Ainda na segunda parte, ao tratar da função do bispo durante a celebração eucarística, o documento faz nova referência, ainda que de passagem, à conversão eucarística, desta vez, porém, com uma linguagem ainda mais simples. Presidindo a oblação da comunidade inteira, o bispo consagra os dons "para que se tornem (deviennent) o corpo e o sangue que a comunidade oferece ${ }^{\prime \prime 70}$. O documento de Valamo, aprovado seis anos depois do documento de Munique, manterá esta mesma sobriedade terminológica ${ }^{71}$.

${ }^{68}$ Munique I, 5c.

${ }^{69}$ Munique I, 4.

${ }^{70}$ Munique II, 3.

${ }^{71}$ Cf. Valamo III, 35. 
As respectivas comissões frisaram a ação transformadora do Espírito nas oblatas. Permanecendo nas oblatas consagradas, o Espírito é comungado junto com o Filho. O documento não investiga o que ocorre no pão e no vinho durante ou depois da ação consecratória, limita-se apenas a confessar a presença eficaz de Cristo nos dons repletos de Espírito.

Católicos e ortodoxos expressaram de comum acordo a santa reserva em relação ao modo da conversão eucarística, atitude expressa pela sobriedade terminológica. Pode ser que a teologia eucarística evdokimoviana, pelo fato de harmonizar-se com as afirmações do documento ecumênico, o tenha inspirado e servido inclusive de plataforma de diálogo. Nenhum dos comentários sobre o acordo ecumênico faz menção a Evdokimov. O que se pode dizer com segurança é que o nosso autor, restringindo-se a uma terminologia não especulativa, mas na linha litúrgico-patrística, já expressara em seus escritos, antes da aprovação dos documentos ecumênicos, a unidade das Igrejas no que concerne à fé eucarística, evidentemente mais como reconhecimento-profissão de fé do que propriamente como explicação da conversão eucarística.

A esperança ecumênica de nosso autor é de que a experiência da santidade poderá unir os cristãos no caminho de busca da verdade trinitária. É justamente com este augúrio que conclui sua obra fundamental, L'Orthodoxie; a nós apraz evocar esse augúrio no final desse trabalho:

Todos e cada um são convidados a aprofundar a presença fulgurante de Cristo, seu nascimento-parusia pelo sopro do Espírito: é no âmbito do milagre dessa natividade pneumatofórica - já reino - que a separação podese mudar em ligame, em unidade. Ortodoxos, católicos e protestantes, percorrendo o caminho da santidade até seu final, que é Cristo, podem se reencontrar, [quais] ícones vivos reunidos em iconóstase do Templo de Deus, sua Porta régia abrindo-se para o abismo do $\mathrm{Pai}^{72}$.

Nedio Pertile OFMCap é Mestre em Teologia Sistemática pela Pontifícia Universidade Gregoriana (Roma) e Doutor em Teologia pela Faculdade de Teologia do ISI-CES (Belo Horizonte, MG). É professor e Diretor da Escola Superior de Teologia e Espiritualidade Franciscana, ESTEF (Porto Alegre-RS) e colabora em cursos de Teologia para leigos.

Endereço: Rua Ernesto di Primio Beck, 325

Vila João Pessoa

91510-490 Porto Alegre - RS

e-mail: nediopertile@terra.com.br

${ }^{72}$ Ort 346. 